Bull. Chem. Soc. Ethiop. 2018, 32(1), 27-38.

ISSN 1011-3924

(C) 2018 Chemical Society of Ethiopia and The Authors

Printed in Ethiopia

DOI: https://dx.doi.org/10.4314/bcse.v32i1.3

\title{
ASSESSMENT OF METALS IN ROASTED INDIGENOUS COFFEE VARIETIES OF ETHIOPIA
}

\author{
Abera Gure ${ }^{1,2}$, Bhagwan Singh Chandravanshi ${ }^{1 *}$ and Taddese Wondimu Godeto ${ }^{1,3}$ \\ ${ }^{1}$ Department of Chemistry, College of Natural Sciences, Addis Ababa University, P.O. Box \\ 1176, Addis Ababa, Ethiopia \\ ${ }^{2}$ Present Address: Department of Chemistry, College of Natural Sciences, Jimma University, \\ P.O. Box 378, Jimma, Ethiopia \\ ${ }^{3}$ Present Address: Laboratory Services Branch, Ministry of the Environment and Climate \\ Change, Etobicoke, Ontario, Canada
}

(Received December 12, 2017; Revised March 29, 2018; Accepted April 4, 2018)

\begin{abstract}
The metals content $(\mathrm{Ca}, \mathrm{Cd}, \mathrm{Cr}, \mathrm{Co}, \mathrm{Cu}, \mathrm{Fe}, \mathrm{K}, \mathrm{Mg}, \mathrm{Mn}, \mathrm{Ni}, \mathrm{Pb}$ and $\mathrm{Zn}$ ) of roasted coffee varieties grown in five different regions of Ethiopia was determined by flame atomic absorption spectrometry. Representative samples were collected from Coffee Quality Inspection and Liquoring Center in the capital city, Addis Ababa, Ethiopia and the metals were extracted by wet digestion. The optimal digestion required 4 hours refluxing at $270{ }^{\circ} \mathrm{C}$ on Kjeldhal hot plate with a mixture of $5 \mathrm{~mL} \mathrm{HNO}_{3}(70 \%)$ and $1.5 \mathrm{~mL} \mathrm{HClO}_{4}(70 \%)$ to completely digest $0.5 \mathrm{~g}$ of roasted coffee samples. Recoveries of metals in the spiked samples varied from 90 to $110 \%$. Analysis of variance revealed significant differences in the concentrations of $\mathrm{Ca}, \mathrm{Co}, \mathrm{Cu}, \mathrm{Mn}, \mathrm{Cr}, \mathrm{Ni}$ and $\mathrm{Zn}$ with the variation of coffee beans geographic origin. Pearson correlation coefficients indicated high positive correlation among some metals and high negative correlation among others. The amounts of metals that a person can get from two cups of coffee are well below the daily recommended values and drinking two cups of coffee is safe for an adult person and free from the risks of $\mathrm{Cd}$ and $\mathrm{Pb}$ toxicity.
\end{abstract}

KEY WORDS: Metals content, Roasted coffee, Indigenous coffee varieties, Ethiopia

\section{INTRODUCTION}

It is commonly believed that the indigenous coffee trees first grew in "Kafa" Province in Ethiopia and the trees were called "Kafa tree", which may as well is the root word for the name of coffee [1,2]. The two main species of coffee exploited in the world at present are Coffea arabica and Coffea conephora (robusta). They account for as large as $99 \%$ of the world's coffee, of which $70 \%$ is Coffea arabica type [2]. Other less cultivated species of Coffea include Coffea liberica, Coffea abeakutyae, Coffea dewevrei, Coffea congensis, etc. Different species of Coffea genus have very diverse appearances and behaviors [1, 3-5].

Ethiopia, exclusively cultivates a number of distinctive regional types of Coffee arabica [68] almost in all the administrative regions of the country. However, the major coffee grower regions are Oromia Regional State and Southern Nations, Nationalities, and Peoples' Region (SNNPR) $[2,3,6]$. There are wide ranges of variability among coffee cultivars in the country and thus, can be classified based on regions or sub-regions of their cultivation and the sizes of coffee berries [7, 8]. Examples of coffee varieties based on areas of their cultivation are; Harar coffee, Wollega coffee, Jimma coffee, Gedeo coffee, Limu coffee, Sidamo coffee, Kaffa coffee, etc. $[7,8]$. The soil, altitude and climate of coffee growing areas have a great influence on the variability of coffee from its body (or chemical contents) to its flavor and aroma [9].

Coffee is one of the most important agricultural products in the international trade. Next to petroleum, coffee is the second in value, putting into motion approximately 35 billion dollars per year [10]. It is a commodity of great economic, social and environmental importance to

*Corresponding author. E-mail: bscv2006@yahoo.com

This work is licensed under the Creative Commons Attribution 4.0 International License 
coffee cultivating countries, particularly for developing countries, like Ethiopia $[1,7,10]$, which generates $60 \%$ of its total export earnings $[1,7]$.

Coffee is the complex mixture of potential "neutriceuticals" [11]. The chemical composition of coffee varies based on species (arabica or robusta), country of origin (Ethiopia, Brazil, Kenya, etc), system of cultivation (organic or conventional) and its physical form as raw or roasted [12-14]. The most important constituents are minerals, lipids, caffeine, proteins, fats, carbohydrates and water $[13,14]$.

Roasting is heating process in which the green coffee beans are nearly made ready for grinding and consumption. Roasting greatly increases the chemical complexity of coffee. Green coffee contains about 250 different volatile molecular species, whereas roasted coffee gives rise to more than 800 [13]. The roasting temperature and the way the process is conducted, which may take $5-25$ minutes, have a considerable effect on the quality of coffee $[15,16]$.

In several studies, metals content of roasted coffee samples have been analyzed for both arabica and robusta coffee types $[10,13,17,18]$. The composition of $\mathrm{Ba}, \mathrm{Ca}, \mathrm{Cu}, \mathrm{Fe}, \mathrm{K}, \mathrm{Mg}$, $\mathrm{Mn}, \mathrm{Na}, \mathrm{P}, \mathrm{Sr}$ and $\mathrm{Zn}$ have been used as chemical descriptors to differentiate between roasted arabica and robusta coffee varieties. According to the report on roasted coffee varieties in southeast Brazilian market, there is a difference in metals content among the samples of roasted coffee varieties [17]. These variations in metal compositions among samples of roasted coffee can indicate the differences in the cultivation of the coffee plants; such as the type of soil, the use of fertilizers with different chemical compositions and the ambient conditions [17].

The minerals bioaccumulations within the coffee beans vary with different trace elements, varieties and environment in which coffee grows $[17,18]$. The amount of elements in plants, generally, depend on many factors; species, age, root distribution of the plant, physical and chemical nature of the soil, proportions and distributions of elements and the general climatic conditions [20-24]. Under most conditions, metallic elements that enter animals are those contained in plants eaten or used as a beverage either directly or indirectly $[19,25,26]$. Thus, the metal content of edible plants frequently controls the amount of these elements available in different animal bodies.

Some recent studies have reported the mineral contents in roasted coffee. Dos Santos et al. [27] have evaluated some metals in Brazilian coffees cultivated during the process of conversion from conventional to organic agriculture. Pohl et al. [28] have described different techniques for the determination of the elemental composition of coffee. Nędzarek et al. [29] have reported the concentrations of six heavy metals ( $\mathrm{Mn}, \mathrm{Co}, \mathrm{Ni}, \mathrm{Cr}, \mathrm{Ag}, \mathrm{Pb}$ ) in coffee infusions from eleven samples, roasted and purchased in four countries: Bosnia and Herzegovina, Brazil, Lebanon and Poland. Cuong et al. [15] have studied the effect of roasting conditions on concentration of nine elements $(\mathrm{K}, \mathrm{Mg}, \mathrm{Ca}, \mathrm{Na}, \mathrm{Fe}, \mathrm{Cu}, \mathrm{Mn}, \mathrm{Zn}$ and $\mathrm{Pb}$ ) of Vietnam robusta coffee.

From the Ethiopian perspective, Ashu and Chandravanshi [30] have reported the concentration of metals $(\mathrm{K}, \mathrm{Mg}, \mathrm{Ca}, \mathrm{Na}, \mathrm{Mn}, \mathrm{Fe}, \mathrm{Cu}, \mathrm{Zn}, \mathrm{Co}, \mathrm{Pb}, \mathrm{Cd})$ in three brands of commercially available Ethiopian roasted coffee powders and their infusions. Gebretsadik et al. [16] have reported the levels of nine metals $(\mathrm{K}, \mathrm{Mg}, \mathrm{Ca}, \mathrm{Na}, \mathrm{Mn}, \mathrm{Cu}, \mathrm{Zn}, \mathrm{Cd}$ and $\mathrm{Pb}$ ) in roasted coffee beans of Yirgacheffe and Sidama, Ethiopia. Mehari et al. [31] have characterized the cultivation region of Ethiopian coffee by elemental analysis. These reports clearly indicate that there is limited information on the mineral contents of roasted coffee cultivated in wider areas of Ethiopia.

Therefore the objectives of this study were (i) to determine selected essential nutrients $(\mathrm{K}$, $\mathrm{Ca}, \mathrm{Mg}, \mathrm{Fe}, \mathrm{Zn}, \mathrm{Mn}, \mathrm{Cu}, \mathrm{Co}, \mathrm{Cr})$ and toxic metals $(\mathrm{Pb}, \mathrm{Ni}, \mathrm{Cd})$ in the roasted indigenous coffee varieties from five different regions of Ethiopia using flame atomic absorption spectrometer (FAAS); (ii) to compare the levels of metals in some Coffea arabica varieties cultivated in five different parts of the country; (iii) to compare the level of metals in Ethiopian coffee varieties with the level of metals in the roasted coffee from other countries and (iv) to compare against 
Assessment of metals in roasted indigenous coffee varieties of Ethiopia

health regulatory limits of the metals in coffee to provide guideline information on the implication of the consumption of these coffee products.

\section{EXPERIMENTAL}

Instruments and apparatus

Coffee Roasting Machine, PROBAT-WERKE BRZ-4 (Von Gimborn Machinenfabrik GmbH, 1997, Germany); a blending device (Moulinex, France) was used for grinding and homogenizing of roasted coffee samples; quick-fit round bottom flasks $(150 \mathrm{~mL})$ fitted with reflux condenser were used in Kjeldahl apparatus hot plate to digest the powdered roasted coffee samples. Buck Scientific Model 210VGP (East Norwalk, USA) and SPECTRAA 20 PLUS (Australia) Flame Atomic Absorption Spectrometer equipped with deuterium ark background correctors were used for analysis of the analyte metals ( $\mathrm{K}, \mathrm{Ca}, \mathrm{Fe}, \mathrm{Zn}, \mathrm{Cu}, \mathrm{Co}, \mathrm{Cr}$, and $\mathrm{Cd}$ ) and $(\mathrm{Mg}, \mathrm{Mn}, \mathrm{Ni}$ and $\mathrm{Pb})$, respectively.

Chemicals, reagents and standard solutions

Chemicals and reagents that were used in the analysis were all analytical grades: $70 \% \mathrm{HNO}_{3}$, (SpectrosoL, BDH, England) and $70 \% \mathrm{HClO}_{4}$ (Analar ${ }^{\mathbb{B},} \mathrm{BDH}$, England) were used for digestion of coffee samples. Lanthanum nitrate hydrate (99.9\%, Sigma Aldrich, Muwaukee, USA) was used for overcoming the loss of $\mathrm{Ca}$ and $\mathrm{Mg}$ as refractory phosphates and/or sulfates in the flame. Stock standard solutions of $\mathrm{K}, \mathrm{Ca}, \mathrm{Fe}, \mathrm{Zn}, \mathrm{Mn}, \mathrm{Cu}, \mathrm{Co}, \mathrm{Cr}, \mathrm{Ni}, \mathrm{Pb}$, and $\mathrm{Cd}(1000 \mathrm{mg}$ element/L, Puro-Graphic $^{\text {tm }}$ calibration standards, Buck Scientific prepared as nitrates for each element in $\left.2 \% \mathrm{HNO}_{3}\right)$ and of $\mathrm{Mg}\left(1000 \mathrm{mg} / \mathrm{L}\right.$ Spectrol ${ }^{\circledR}$ (BDH Chemicals Ltd, England), $\mathrm{Mg}\left(\mathrm{NO}_{3}\right)_{2}$, standard solution) were used for the preparation of a series of calibration standards for the determination of metals in the samples. Deionized water was used for cleaning of glassware and dilution of sample solutions.

\section{Description of study area}

There are large numbers of $C$. arabica varieties that are grown in different parts of Ethiopia. Even though, the demarcation between the varieties is not clear and simple, experts or researchers classify Ethiopian coffees based upon the Farmland, Kebele, Woreda or Zones in which they grow $[1,7,8]$. Wollega coffee is cultivated in highland of west Ethiopia and is valued for its flavor and large bean size. It includes coffee varieties that are grown in three zones of the country Kelem Wollega, East Wollega and West Wollega zones. Sidamo and Bench Maji coffee varieties are grown in the south and south western high and low lands of SNNPR, respectively. Beans of these coffee varieties are medium sized and greenish in color. Harar coffee is the most common coffee type that is produced in the Eastern highlands of the country, in east and west Hararghe zones. It is one of the finest premium coffees in the world and is grown at an altitude of 2000 - 2750 meters. Kafa coffee is also grown in SNNPR of Ethiopia, which is the historical origin of coffee. The choice of these varieties and growing zones was based on different factors such as propensity to supply for export, their historical coffee growing tradition, domestic use, etc. In general, these zones are the most coffee growing regions for a long period of time. They are also the most coffee suppliers of both unwashed and washed dry coffee for domestic use and international markets $[1,32]$. 
Sample collection

Coffee samples were collected from the Coffee Quality Inspection and Liquoring Center, Addis Ababa, Ethiopia. The choice of site was based on availability of the different coffee varieties. A total of five green coffee varieties were collected (100 g composite sample from a multiple subsites). Names of these coffee types and altitude are given in Table 1.

Table 1. Names of coffee types, elevation, moisture content and roasting conditions.

\begin{tabular}{|c|l|c|c|c|c|}
\hline S. No. & Coffee variety & Elevation & $\begin{array}{c}\text { Mosture } \\
(\%)\end{array}$ & $\begin{array}{c}\text { Roasting } \\
\text { temp. }\left({ }^{\circ} \mathrm{C}\right)\end{array}$ & $\begin{array}{c}\text { Roasting time } \\
(\mathrm{min})\end{array}$ \\
\hline 1 & Wollega coffee & High land & 8.6 & 180 & 7 \\
\hline 2 & Sidamo coffee & High land & 9.8 & 180 & 7 \\
\hline 3 & Harar coffee & High land & 9.1 & 175 & 6 \\
\hline 4 & Kafa coffee & High/low land & 9.5 & 160 & 7 \\
\hline 5 & Bench Maji coffee & Low land & 9.9 & 195 & 7 \\
\hline
\end{tabular}

Pretreatment of coffee samples

About $100 \mathrm{~g}$ of each coffee sample was roasted using coffee roasting machine at sample collection site. All the roasting process was carried out by an expert coffee roaster from Coffee Quality Inspection and Liquoring Center (Addis Ababa, Ethiopia). The roasting conditions are given in Table 1. All the roasted coffee samples were cooled to room temperature, packaged in polyethylene plastic bags, transported to the laboratory and stored until they were ground by blending device.

\section{Digestion of roasted coffee samples}

The method proposed by Suseela et al. [33] was tested for digestion of the ground roasted coffee samples using a mixture of $70 \% \mathrm{HNO}_{3}, 70 \% \mathrm{HClO}_{4}$ and $30 \% \mathrm{H}_{2} \mathrm{O}_{2}$. Different attempts were under taken in order to develop another simple alternative procedure that require shorter reflux time/digestion time as well as reduced types and volumes of the reagents. Accordingly, series of procedures involving changes of reagents volume, reagents composition and digestion temperature and digestion time were investigated and the optimal conditions were established. The results for tested modifications of the open-vessel digestion procedure are given in Table 2.

The optimum procedure used in the analysis of the roasted coffee samples was carried out as follows: A $0.5 \mathrm{~g}$ of powdered roasted coffee samples was added into a round bottom flask (150 $\mathrm{mL})$. To this flask, $4.0 \mathrm{~mL} \mathrm{HNO}_{3}(70 \%)$ and $1 \mathrm{~mL} \mathrm{HClO}_{4}(70 \%)$ were added and the mixture digested on a micro Kjeldahl digestion flask at $270{ }^{\circ} \mathrm{C}$ for $2 \mathrm{~h}$. After addition of $1.0 \mathrm{~mL} \mathrm{HNO}_{3}$ $(70 \%)$ and $0.5 \mathrm{~mL} \mathrm{HClO}_{4}(70 \%)$, the digestion was continued for additional $2 \mathrm{~h}$. The residue obtained after a $4 \mathrm{~h}$ digestion period was allowed to cool down for $30 \mathrm{~min}$ in an open air. About $40 \mathrm{~mL}$ of deionized water was added to dissolve the residue and to also minimize the dissolution of the filter media while filtrating. The filtrate was diluted to $50 \mathrm{~mL}$ with deionized water. The diluted samples were kept in the refrigerator below $4{ }^{\circ} \mathrm{C}$ until analysis by FAAS in about 2-4 weeks. 
Assessment of metals in roasted indigenous coffee varieties of Ethiopia

Table 2. Procedures tested for digestion of roasted coffee samples.

\begin{tabular}{|c|c|c|c|c|c|}
\hline No. & $\begin{array}{l}\text { Sample } \\
\text { mass }(\mathrm{g})\end{array}$ & $\begin{array}{l}\text { Reagents added } \\
70 \% \text { of } \mathrm{HNO}_{3}, \mathrm{HClO}_{4} \text {, } \\
\text { and } 30 \% \mathrm{H}_{2} \mathrm{O}_{2}\end{array}$ & $\begin{array}{l}\text { Digestion } \\
\text { temp. }\left({ }^{\circ} \mathrm{C}\right)\end{array}$ & $\begin{array}{l}\text { digestion } \\
\text { time (h) }\end{array}$ & Appearance of filtered digests \\
\hline 1 & 1.0 & $\begin{array}{l}3.0 \mathrm{~mL} \mathrm{HNO}_{3} \\
1.5 \mathrm{~mL} \mathrm{HClO}_{4}\end{array}$ & 240 & 3.0 & Turbid \\
\hline 2 & 1.0 & $\begin{array}{l}3.0 \mathrm{~mL} \mathrm{HNO}_{3} \\
1.5 \mathrm{~mL} \mathrm{HClO}_{4} \\
\end{array}$ & 240 & 4.5 & Clear but pale yellowish \\
\hline 3 & 0.5 & $\begin{array}{l}6.0 \mathrm{~mL} \mathrm{HNO}_{3} \\
1.5 \mathrm{~mL} \mathrm{HClO}_{4} \\
\end{array}$ & 240 & 4.5 & Clear but pale yellowish \\
\hline 4 & 0.5 & $\begin{array}{l}6.0 \mathrm{~mL} \mathrm{HNO}_{3} \\
1.5 \mathrm{~mL} \mathrm{HClO}_{4} \\
2.0 \mathrm{~mL} \mathrm{H}_{2} \mathrm{O}_{2} \\
\end{array}$ & 240 & 4.5 & Clear but pale yellowish \\
\hline 5 & 0.5 & $\begin{array}{l}5.0 \mathrm{~mL} \mathrm{HNO}_{3} \\
1.0 \mathrm{~mL} \mathrm{HClO}_{4}\end{array}$ & 270 & 3.0 & Clear but pale yellowish \\
\hline 6 & 0.5 & \begin{tabular}{|l|}
$5.0 \mathrm{~mL} \mathrm{HNO}_{3}$ \\
$1.5 \mathrm{~mL} \mathrm{HClO}_{4}$ \\
\end{tabular} & 270 & 4.0 & Clear and colorless (Optimum) \\
\hline 7 & 0.5 & $\begin{array}{l}4.0 \mathrm{~mL} \mathrm{HNO}_{3} \\
1.5 \mathrm{~mL} \mathrm{HClO}_{4} \\
\end{array}$ & 270 & 4.0 & Clear and pale yellow \\
\hline 8 & 0.5 & $\begin{array}{l}9.0 \mathrm{~mL} \mathrm{HNO}_{3} \\
1.5 \mathrm{~mL} \mathrm{HClO}_{4} \\
\end{array}$ & 270 & 4.5 & Clear but weakly pale yellow \\
\hline 9 & 0.5 & $\begin{array}{l}8.0 \mathrm{~mL} \mathrm{HNO}_{3} \\
1.5 \mathrm{~mL} \mathrm{HClO}_{4}\end{array}$ & 270 & 5.5 & Clear and colorless \\
\hline 10 & 0.5 & $\begin{array}{l}6.0 \mathrm{~mL} \mathrm{HNO}_{3} \\
1 \mathrm{~mL} \mathrm{H}_{2} \mathrm{SO}_{4} \\
1.5 \mathrm{~mL} \mathrm{HClO}_{4} \\
\end{array}$ & 270 & 5.0 & Turbid \\
\hline
\end{tabular}

Note: The bold font indicates the optimum condition. In all cases the residue of the digest contains white precipitates, which was dissolved upon addition of water.

\section{Determination of metals in the coffee samples}

For the determination of metals in the roasted coffee samples, four series of standard metal solutions were prepared by diluting the stock solutions of the metal with deionized water. A blank (deionized water) and standards were run in FAAS and four points of calibration curve were established for each metal. The correlation coefficients of the calibration curves were very good ( $>0.999)$. Sample solutions were each aspirated into the FAAS instrument and direct readings of the metal concentrations were recorded. Three replicate determinations were carried out on each sample.

\section{Accuracy and precision}

In this study, the precision of the results was evaluated by the standard deviation of the results of triplicate samples $(n=3)$ analyzed under the same conditions [34]. The accuracy and validity of the measurement were determined by analyzing spiked samples using standard solutions [34].

The procedure of spiking was as follows: for the determination of the validity of the developed optimized procedures used for determination of metals in the roasted coffee bean samples, known concentration of standard solutions (that is $100 \mathrm{mg} / \mathrm{L}$ of $\mathrm{Ca}, \mathrm{Cr}, \mathrm{Co}, \mathrm{Cu}, \mathrm{Fe}, \mathrm{K}$, $\mathrm{Mg}, \mathrm{Mn}, \mathrm{Ni}, \mathrm{Pb}$ and $\mathrm{Zn}$ and $10 \mathrm{mg} / \mathrm{L}$ of $\mathrm{Cd}$ ) were prepared. From these solutions, suitable amounts that would make the final solution concentration of $0.30 \mathrm{mg} / \mathrm{L}(\mathrm{Ca}, \mathrm{K}$ and $\mathrm{Mg}), 0.20$ $\mathrm{mg} / \mathrm{L}(\mathrm{Cr}, \mathrm{Co}, \mathrm{Cu}, \mathrm{Fe}, \mathrm{Mn}, \mathrm{Ni}, \mathrm{Pb}$ and $\mathrm{Zn})$ and $0.02 \mathrm{mg} / \mathrm{L}(\mathrm{Cd}) ; 0.15,0.10$ and $0.10 \mathrm{~mL}$, respectively, were added to $0.50 \mathrm{~g}$ of roasted coffee samples. The resulting mixtures were digested with the optimum digestion procedure for the roasted coffee samples. After diluting the 
spiked samples to the required volume (i.e., $50 \mathrm{~mL}$ ) with deionized water, the metals content was analyzed by FAAS. Triplicate samples were prepared and triplicate readings were obtained.

\section{Determination of method detection and quantitation limits}

A general accepted definition of method detection limit (MDL) is the concentration that gives a signal three times the standard deviation of the blank or background signal $[9,34,35]$. In this study the MDL of each element was calculated as three times the standard deviation of the blank $\left(3 \sigma_{\text {blank, }} \mathrm{n}=5\right)$. Method quantitation limit $(\mathrm{MQL})$ is the lowest limit for precise quantitative measurements [36]. The MQL is the same as the concentration that gives a signal 10 times the standard deviation of the blank [34]. The MQL of each element was calculated as ten times the standard deviation of the blank $\left(10 \sigma_{\text {blank, }} \mathrm{n}=5\right)$.

Data analysis

Microsoft office Excel 2007 was utilized for the construction of calibration curves and data analysis. Statistical software SPSS 20 was used for one way analysis of variance (ANOVA) to compare the mean values of the metals among various coffee samples at $p=0.05$. The degree of positive or negative correlation between the metals was assessed using Pearson correlation coefficient.

\section{RESULTS AND DISCUSSION}

\section{Optimization of digestion procedure}

A total of ten procedures were tested for digestion of roasted coffee samples by varying reagent volume, reagent composition, digestion temperature and digestion time. The optimized procedure was selected based on: clarity of digests, minimal reflux time/digestion time, minimal reagent volume consumption, absence of undigested sample particles, simplicity and acceptable use of masses of coffee samples.

Based on these criteria, the optimal digestion procedure required $4 \mathrm{~h}$ for complete digestion of $0.50 \mathrm{~g}$ of coffee powders with $5 \mathrm{~mL} \mathrm{HNO}_{3}(70 \%)$ and $1.5 \mathrm{~mL} \mathrm{HClO}_{4}(70 \%)$ at $270{ }^{\circ} \mathrm{C}$. This procedure was developed with some modifications of the literature procedure [33] used to measure the trace metal content in different brands of coffee products in Indian market by FAAS. However, the other tested procedures have some limitation to fulfill the stated criteria. All other procedures that required higher reagent volumes, took longer digestion time, accommodate smaller sample mass or produced turbid or colored digests were rejected.

\section{Validation of optimized procedure}

The accuracy of the optimized procedure was evaluated by analyzing the digests of spiked samples of roasted coffee. The recoveries of metals in the spiked coffee samples were $90 \%$ to $110 \%$ which are within the acceptable range $(100 \pm 10 \%)$. Thus the optimized procedure was found to have good accuracy.

Determination of the metals

The concentrations of major and trace metallic elements in the roasted coffee samples are given in Table 3. 
Assessment of metals in roasted indigenous coffee varieties of Ethiopia

Table 3. Mean concentration ( $\mathrm{X} \pm \mathrm{SD}, \mathrm{n}=3, \mathrm{mg} / \mathrm{kg}$ dry weight) of major metals in the roasted coffee samples.

\begin{tabular}{|c|c|c|c|c|c|}
\hline Metal & Wollega coffee & Sidamo coffee & Harar coffee & Bench Maji coffee & Kafa coffee \\
\hline $\mathrm{K}$ & $16100 \pm 1040^{\mathrm{a}}$ & $16100 \pm 800^{\mathrm{a}}$ & $14900 \pm 1100^{\mathrm{a}}$ & $19400 \pm 970^{\mathrm{a}}$ & $14300 \pm 100^{\mathrm{a}}$ \\
\hline $\mathrm{Mg}$ & $1670 \pm 30^{\mathrm{b}}$ & $1750 \pm 70^{\mathrm{b}}$ & $1770 \pm 10^{\mathrm{b}}$ & $1840 \pm 70^{\mathrm{b}}$ & $1890 \pm 20^{\mathrm{b}}$ \\
\hline $\mathrm{Ca}$ & $790 \pm 20^{\mathrm{c}}$ & $930 \pm 60^{\mathrm{d}}$ & $1380 \pm 20^{\mathrm{e}}$ & $1050 \pm 50^{\mathrm{f}}$ & $1530 \pm 60^{\mathrm{g}}$ \\
\hline $\mathrm{Cd}$ & $<0.01$ & $<0.01$ & $<0.01$ & $<0.01$ & $<0.01$ \\
\hline $\mathrm{Cr}$ & $0.43 \pm 0.030^{\mathrm{h}}$ & $0.55 \pm 0.01^{1}$ & $0.52 \pm 0.01^{1}$ & $0.53 \pm 0.02^{1}$ & $0.56 \pm 0.01^{1}$ \\
\hline $\mathrm{Co}$ & $15.40 \pm 0.08^{\mathrm{j}}$ & $5.80 \pm 0.03^{\mathrm{k}}$ & $7.50 \pm 0.02^{1}$ & $8.20 \pm 0.03^{1}$ & $19.30 \pm 0.50^{\mathrm{m}}$ \\
\hline $\mathrm{Cu}$ & $22.70 \pm 1.00^{\mathrm{n}}$ & $27.60 \pm 3.00^{\mathrm{o}}$ & $19.60 \pm 1.00^{\mathrm{p}}$ & $19.50 \pm 1.00^{\mathrm{p}}$ & $13.00 \pm 1.00^{\mathrm{q}}$ \\
\hline $\mathrm{Fe}$ & $41.00 \pm 4.00^{\mathrm{r}}$ & $37.30 \pm 1.50^{\mathrm{r}}$ & $46.00 \pm 2.00^{\mathrm{r}}$ & $39.90 \pm 2.00^{\mathrm{r}}$ & $47.50 \pm 5.50^{\mathrm{r}}$ \\
\hline $\mathrm{Mn}$ & $15.00 \pm 0.70^{\mathrm{s}}$ & $20.00 \pm 1.00^{\mathrm{t}}$ & $15.00 \pm 0.70^{\mathrm{s}}$ & $17.00 \pm 0.70^{\mathrm{s}}$ & $19.00 \pm 1.00^{\mathrm{t}}$ \\
\hline $\mathrm{Ni}$ & $2.00 \pm 0.01^{\mathrm{u}}$ & $2.00 \pm 0.01^{\mathrm{u}}$ & $3.50 \pm 0.02^{\mathrm{v}}$ & $1.00 \pm 0.01^{\mathrm{w}}$ & $1.00 \pm 0.01^{\mathrm{w}}$ \\
\hline $\mathrm{Pb}$ & $<0.05$ & $<0.05$ & $<0.05$ & $0.06 \pm 0.01$ & $0.07 \pm 0.01$ \\
\hline $\mathrm{Zn}$ & $19.70 \pm 0.08^{\mathrm{x}}$ & $30.40 \pm 0.50^{\mathrm{y}}$ & $21.30 \pm 0.10^{\mathrm{x}}$ & $14.10 \pm 0.04^{\mathrm{x}}$ & $6.00 \pm 0.05^{\mathrm{z}}$ \\
\hline
\end{tabular}

The same letter indicated that the values were not significantly different at $p=0.05$, according to Duncan's multiple range test.

The concentrations of these elements in different coffee types were varied in the roasted coffee samples. The ranges of macro elements $(\mathrm{Ca}, \mathrm{K}$ and $\mathrm{Mg})$ were found to be: $1530 \pm 60$ $790 \pm 20,14300 \pm 1000-19400 \pm 970,16700 \pm 30-1890 \pm 20 \mathrm{in} \mathrm{mg} / \mathrm{kg}$, respectively (Table $3)$. On the other hand, the ranges of the concentration of trace metals, $(\mathrm{Cr}, \mathrm{Co}, \mathrm{Cu}, \mathrm{Fe}, \mathrm{Mn}, \mathrm{Ni}$ and $\mathrm{Zn}$ ) (Table 3) found to be: $0.43 \pm 0.03-0.56 \pm 0.01,5.80 \pm 0.03-19.3 \pm 0.50,13.0 \pm 1.00-$ $27.60 \pm 1.00,37.3 \pm 1.50-47.5 \pm 5.50,15.0 \pm 0.70-20.0 \pm 1.00,1.00 \pm 0.01-3.50 \pm 0.02$ and $6.00 \pm 0.05-30.40 \pm 0.50 \mathrm{in} \mathrm{mg} / \mathrm{kg}$, respectively. Cd concentration was below the MDL for the all coffee varieties studied. Similarly, $\mathrm{Pb}$ was also found to be below the MDL, with exception of Bench Maji and Kafa coffee in which its concentration was 0.06 and $0.07 \mathrm{mg} / \mathrm{kg}$, respectively.

\section{Distribution pattern of metals in different coffee samples}

The distribution and accumulation of metals in coffee beans are a distorted reflection of the mineral composition of the soil and environment in which the coffee plant grows [31]. The soil plant system is highly specific for different elements, plant species and environmental conditions $[22,24,26]$. Under most conditions, metallic elements in coffee beans must have existed in the rooting zone of the plant, at least in a slightly soluble form. Therefore, the actual metal content of coffee beans vary considerably according to coffee species, geographic origin, coffee type, the use of fertilizers with different chemical compositions and other characterizing features [13, 19]. Suseela et al. [33] and Martin et al. [17, 18] have reported that the metal contents of coffee beans are one of the important parameter to differentiate between coffee varieties, arabica and robusta. They have also reported the geographical dependence of the elemental content of coffee beans, which are produced from the same coffee species.

One way analysis of variances (ANOVA) at $95 \%$ confidence level was used to compare the mean values of metals in the five varieties of coffee samples. As shown in Table 3, the one way ANOVA study revealed that there were no significant differences between the five coffee bean samples in terms of their content of $\mathrm{K}, \mathrm{Mg}$ and $\mathrm{Fe}$. However, the studied coffee samples exhibited significant differences in the concentrations of $\mathrm{Ca}, \mathrm{Co}, \mathrm{Cu}, \mathrm{Fe}, \mathrm{Mn}, \mathrm{Cr}$, Ni and $\mathrm{Zn}$ with the variation of coffee beans geographic origin. 


\section{Pearson correlation}

To assess the correlation between the metals' concentrations in the roasted coffee samples, the Pearson correlation coefficient ( $r$ ) was used [34]. As can be seen in Table 4, the values of Pearson correlation coefficient indicated that there are weak, moderate, and strong positive and/or negative correlations between the metals. The weak negative and weak positive correlation indicates that the availability or absence of one metal has less effect on the other. But, the observed high positive correlation for $\mathrm{Mg}$ with $\mathrm{Co}$; $\mathrm{Ca}$ with $\mathrm{Co}$ and $\mathrm{Fe}$; $\mathrm{Cr}$ with $\mathrm{Mn}$; as well as $\mathrm{Co}$ with $\mathrm{Fe}$ might be due to their common anthropogenic or natural sources. The high negative correlation observed for $\mathrm{Mg}$ and $\mathrm{Cu}, \mathrm{Ni}$ and $\mathrm{Zn}$; $\mathrm{Ca}$ with $\mathrm{Cu}$; $\mathrm{Co}$ with $\mathrm{Cu}$ and $\mathrm{Zn}$; and $\mathrm{Cu}$ with $\mathrm{Fe}$ may indicate different sources of the metals.

Table 4. Pearson correlation matrices for metals in roasted coffee samples $(n=5)$.

\begin{tabular}{|c|c|c|c|c|c|c|c|c|c|c|}
\hline & $\mathrm{K}$ & $\mathrm{Mg}$ & $\mathrm{Ca}$ & $\mathrm{Cr}$ & $\mathrm{Co}$ & $\mathrm{Cu}$ & $\mathrm{Fe}$ & $\mathrm{Mn}$ & $\mathrm{Ni}$ & $\mathrm{Zn}$ \\
\hline $\mathrm{K}$ & 1.00 & & & & & & & & & \\
\hline $\mathrm{Mg}$ & 0.01 & 1.00 & & & & & & & & \\
\hline $\mathrm{Ca}$ & -0.69 & 0.57 & 1.00 & & & & & & & \\
\hline $\mathrm{Cr}$ & -0.36 & 0.42 & 0.12 & 1.00 & & & & & & \\
\hline $\mathrm{Co}$ & -0.47 & 0.87 & 0.78 & 0.63 & 1.00 & & & & & \\
\hline $\mathrm{Cu}$ & 0.28 & -0.88 & -0.87 & -0.16 & -0.86 & 1.00 & & & & \\
\hline $\mathrm{Fe}$ & -0.66 & 0.52 & 0.99 & 0.02 & 0.71 & -0.86 & 1.00 & & & \\
\hline $\mathrm{Mn}$ & -0.09 & 0.12 & -0.31 & 0.91 & 0.25 & 0.25 & -0.41 & 1.00 & & \\
\hline $\mathrm{Ni}$ & -0.40 & -0.74 & 0.10 & -0.62 & -0.51 & 0.32 & 0.17 & -0.59 & 1.00 & \\
\hline $\mathrm{Zn}$ & 0.07 & -0.97 & -0.70 & -0.25 & -0.86 & 0.96 & -0.68 & 0.10 & 0.57 & 1.00 \\
\hline
\end{tabular}

Comparison of observed metals concentration with the reported values

Many researchers have reported the concentration of metals in the roasted coffee varieties, which are grown in the different part of the world. For instance, the mineral content of roasted coffee beans that are grown in the different parts of the world; such as Brazil [10, 18], different countries including Colombia, Costa Rica, Ivory Cost, Mexico, and Uganda [19], Nigeria [35], and India [33] have been reported. The comparative study of the observed results from this study and reported values are presented in Table 5.

Table 5. Comparison of metals concentration, ( $\mathrm{mg} / \mathrm{kg}$, dry mass) in Ethiopian roasted coffee beans with the reported values.

\begin{tabular}{|l|l|l|l|l|l|l|}
\hline Metal & $\begin{array}{l}\text { Ethiopian coffee } \\
\text { present study) }\end{array}$ & $\begin{array}{l}\text { Brazilian coffee } \\
{[10]}\end{array}$ & $\begin{array}{l}\text { Indian coffee } \\
{[33]}\end{array}$ & $\begin{array}{l}\text { Brazilian } \\
\text { coffee [18] }\end{array}$ & $\begin{array}{l}\text { Different countries } \\
\text { coffee [19] }\end{array}$ & $\begin{array}{l}\text { Nigerian } \\
\text { coffee [35] }\end{array}$ \\
\hline $\mathrm{Ca}$ & $790-1540$ & $1110-1890$ & $490-791$ & $890-1010$ & $934-1234$ & NR \\
\hline $\mathrm{Cd}$ & $\mathrm{ND}$ & $\mathrm{NR}$ & $0.001-0.03$ & $\mathrm{NR}$ & $\mathrm{NR}$ & $0.02-0.31$ \\
\hline $\mathrm{Cr}$ & $0.43-0.56$ & $\mathrm{ND}$ & $0.7-0.8$ & $\mathrm{NR}$ & $\mathrm{NR}$ & $0.89-6.98$ \\
\hline $\mathrm{Co}$ & $6-19$ & $\mathrm{NR}$ & $\mathrm{NR}$ & $\mathrm{NR}$ & $\mathrm{NR}$ & $0.1-14$ \\
\hline $\mathrm{Cu}$ & $13-28$ & $0.5-23$ & $0.4-16$ & $13-18$ & $13-8$ & $2-9$ \\
\hline $\mathrm{Fe}$ & $37-48$ & $14-450$ & $16-92$ & $50-60$ & $12-31$ & $6-174$ \\
\hline $\mathrm{K}$ & $14310-19400$ & $32500-39800$ & $14000-29000$ & $14070-14660$ & $17500-19600$ & $\mathrm{NR}$ \\
\hline $\mathrm{Mg}$ & $1870-1890$ & $2120-4150$ & $2000-3100$ & $1730-1940$ & $2058-2347$ & $\mathrm{NR}$ \\
\hline $\mathrm{Mn}$ & $15-20$ & $4-39$ & $7-13$ & $27-30$ & $19-39$ & $\mathrm{NR}$ \\
\hline $\mathrm{Ni}$ & $1.0-3.5$ & $\mathrm{NR}$ & $0.6-2.0$ & $\mathrm{NR}$ & $\mathrm{NR}$ & $0.04-2.58$ \\
\hline $\mathrm{Pb}$ & $\mathrm{ND}$ & $\mathrm{NR}$ & $0.02-0.2$ & $\mathrm{NR}$ & $\mathrm{NR}$ & $0.09-0.91$ \\
\hline $\mathrm{Zn}$ & $6-30$ & $3-15$ & $2-9$ & $5-29$ & $6-8$ & $4-14$ \\
\hline
\end{tabular}

$\mathrm{ND}=$ not detected (below detection limit); $\mathrm{NR}=$ not reported 
Assessment of metals in roasted indigenous coffee varieties of Ethiopia

The results presented in Table 5 shows that the metals content observed in the roasted coffee beans in this study are more or less comparable with the reported literature values. However, relatively lower concentration of $\mathrm{K}$ is observed in this study in comparison to the reported values. This may probably confirm that Ethiopian coffee is cultivated without the use of fertilizers. In addition, concentration of $\mathrm{Cr}$ is lower than the reported results in the roasted samples. The concentrations of $\mathrm{Co}, \mathrm{Cu}$, and $\mathrm{Ni}$ are slightly higher than the reported values. In general, the consistencies of observed results with the reported values give an additional confirmation for the validity of this study.

Daily intake of metals from roasted coffee

Daily intake of metals from the roasted coffee was calculated based on the assumption that an adult person consumes an average of $5 \mathrm{~g}$ dry roasted coffee (two cups of coffee) per day and is given in Table 6.

The amounts of all the metals that a person can assimilate from two cups of coffee are well below the daily recommended values. This indicates that consumption of $5 \mathrm{~g}$ of the roasted coffee, which is equivalent to two cups of coffee is safe for an adult person. It also indicates that drinking two cups of coffee daily can be a good source of the essential metals but not sufficient enough to meet the daily requirement. Therefore, a consumer must get supplementary intake of essential metals from other sources. Since the levels of $\mathrm{Cd}$ and $\mathrm{Pb}$ in the roasted coffee samples are almost negligible, it is possible that consumers may be free from the risks of $\mathrm{Cd}$ and $\mathrm{Pb}$ as a result of drinking two cups of coffee prepared from the roasted coffee per day.

Table 6. Comparison of daily intake of metals from the roasted coffee with recommended daily intake and tolerable upper limit of daily intake of metals $[37,38]$.

\begin{tabular}{|c|l|l|l|l|}
\hline Metal & $\begin{array}{l}(\mathrm{mg} / \mathrm{kg}) \quad \text { from } \\
\text { roasted coffee }\end{array}$ & $\begin{array}{l}\text { (mg) from 5 g roasted } \\
\text { coffee }\end{array}$ & $\begin{array}{l}\text { Daily recommended } \\
\text { intake }\end{array}$ & Tolerable upper limit \\
\hline $\mathrm{Ca}$ & $790-1530$ & $3.95-7.65$ & $1000-1200 \mathrm{mg}$ & $2500 \mathrm{mg} / \mathrm{day}$ \\
\hline $\mathrm{Mg}$ & $1670-1890$ & $8.35-9.45$ & $320-420 \mathrm{mg}$ & $750 \mathrm{mg} /$ day \\
\hline $\mathrm{K}$ & $14300-19400$ & $71.5-97.0$ & $4700 \mathrm{mg}$ & $\mathrm{ND}^{*}$ \\
\hline $\mathrm{Cr}$ & $0.43-0.56$ & $0.00215-0.0028$ & $25-35 \mu \mathrm{g}$ & $120 \mu \mathrm{g} / \mathrm{day}$ \\
\hline $\mathrm{Cu}$ & $13.0-27.6$ & $0.065-0.138$ & $0.9-2 \mathrm{mg}$ & $10 \mathrm{mg} / \mathrm{day}$ \\
\hline $\mathrm{Fe}$ & $37.3-47.5$ & $0.1865-0.2375$ & $10-15 \mathrm{mg}$ & $45 \mathrm{mg} / \mathrm{day}$ \\
\hline $\mathrm{Mn}$ & $15.0-20.0$ & $0.075-0.100$ & $1.8-2.3 \mathrm{mg}$ & $11 \mathrm{mg} / \mathrm{day}$ \\
\hline $\mathrm{Ni}$ & $1.00-2.00$ & $0.005-0.010$ & $70-170 \mu \mathrm{g} / \mathrm{kg}$ & $1 \mathrm{mg} / \mathrm{day}$ \\
\hline $\mathrm{Zn}$ & $6.00-30.40$ & $0.030-0.152$ & $10-15 \mathrm{mg}$ & $40 \mathrm{mg} / \mathrm{day}$ \\
\hline $\mathrm{Cd}$ & $<0.01$ & $<0.0005$ & $\mathrm{ND}$ & $7 \mu \mathrm{g} / \mathrm{kg} \mathrm{bw} / \mathrm{week}$ \\
\hline $\mathrm{Pb}$ & $<0.05-0.07$ & $<0.00025-0.00035$ & $0.02-3 \mu \mathrm{g} / \mathrm{kg} \mathrm{bw}$ & $25 \mu \mathrm{g} / \mathrm{kg} \mathrm{bw} / \mathrm{day}$ \\
\hline $\mathrm{Co}$ & $5.80-19.30$ & $0.029-0.0965$ & $5-40 \mathrm{~g} / \mathrm{day}$ & $0.25 \mathrm{mg} / \mathrm{day}$ \\
\hline
\end{tabular}

"Indicates the estimated daily intake, bw = body weight, $\mathrm{ND}=$ not determined.

\section{CONCLUSION}

An efficient procedure for digestion of roasted coffee was developed and validated through recovery studies, which reduced blank levels through use of minimum acid volumes, and resulted in low detection and quantitation limits, and created analytical conditions with greater precision and accuracy. Although, the data set is relatively small to draw authoritative conclusions about the metals content of roasted Ethiopian coffee beans, the investigation has indicated the presence of macro essential $(\mathrm{Ca}, \mathrm{K}$, and $\mathrm{Mg})$ and micro essential $(\mathrm{Cr}, \mathrm{Co}, \mathrm{Cu}, \mathrm{Fe}$, $\mathrm{Mn}$ and $\mathrm{Zn}$ ) elements. Except for $\mathrm{K}, \mathrm{Mg}$ and $\mathrm{Fe}$, the metals exhibited variations with the 
geographic origin of coffee samples. The observed positive correlations of $\mathrm{Mg}$ with $\mathrm{Co}$; $\mathrm{Ca}$ with $\mathrm{Co}$ and $\mathrm{Fe}$; $\mathrm{Cr}$ with $\mathrm{Mn}$; as well as $\mathrm{Co}$ with $\mathrm{Fe}$, could be due to common anthropogenic or natural sources. On the other hand, negative correlation observed for $\mathrm{Mg}$ and $\mathrm{Cu}, \mathrm{Ni}$ and $\mathrm{Zn} ; \mathrm{Ca}$ with $\mathrm{Cu}$; $\mathrm{Co}$ with $\mathrm{Cu}$ and $\mathrm{Zn}$; and $\mathrm{Cu}$ with $\mathrm{Fe}$ might be indicative of a different source of these metals. Negligible amounts of $\mathrm{Cd}$ and $\mathrm{Pb}$ are present in Ethiopian coffee relative to coffee varieties from some other countries. The study revealed that drinking two cups of coffee per day is safe for an adult person and free from the risks of $\mathrm{Cd}$ and $\mathrm{Pb}$ toxicity.

\section{ACKNOWLEDGEMENTS}

The authors are grateful to the Department of Chemistry, College of Natural Sciences, Addis Ababa University, Addis Ababa, Ethiopia for providing laboratory facilities and financial support. The first author is also thankful to Oromia Education Bureau, Ministry of Education, Ethiopia, for sponsoring his study.

\section{REFERENCES}

1. Amamo, A.A. Coffee production and marketing in Ethiopia. Eur. J. Business Manage. 2014, 6, 109-121.

2. Gebeyehu, B.T.; Bikila, S.L. Determination of caffeine content and antioxidant activity of coffee. Am. J. Appl. Chem. 2015, 3, 69-76.

3. Belete, Y.; Belachew, B.; Fininsa, C. Evaluation of bean qualities of indigenous Arabica coffee genotypes across different environments. J. Plant Breed. Crop Sci. 2014, 6, 135-143.

4. Barbin, D.F.; Felicio, A.L.S.M.; Sun, D.; Nixdorf, S.L.; Hirooka, E.Y. Application of infrared spectral techniques on quality and compositional attributes of coffee: An overview. Food Res. Int. 2014, 61, 23-32.

5. Jeszka-Skowron, M.; Zgola-Grzeskowiak, A.; Grzeskowiak, T. Analytical methods applied for the characterization and the determination of bioactive compounds in coffee. Eur. Food Res. Technol. 2015, 240, 19-31.

6. Demissie, E.G.; Woyessa, G.W.; Abebe, A. UV-VIS spectrometer determination of caffeine in green coffee beans from Hararghe, Ethiopia, using Beer-Lambert's law and integrated absorption coefficient techniques. Sci. Study Res. Chem. Chem. Eng. Biotechnol. Food Ind. 2016, 17, 109-123.

7. Kufa, T.; Ayano, A.; Yilma, A.; Kumela, T.; Tefera, W. The contribution of coffee research for coffee seed development in Ethiopia. E3 J. Agric. Res. Dev. 2011, 1, 9-16.

8. Tessema, A.; Alamerew, S.; Kufa, T.; Garedew, W. Variability and association of quality and biochemical attributes in some promising Coffea arabica germplasm collections in southwestern Ethiopia. Int. J. Plant Breed. Gen. 2011, 5, 302-316.

9. Shalander, K.; Francis, B.; Pazo, E.A.; Taye, K.; Africa, Z.; Julius, O. Research and Development Options for Enhancing Income and Sustainability of Farming Systems in KafaSheka Zone of Ethiopia, International Centre for Development Oriented Research in Agriculture, Wageningen, The Netherlands; 2000.

10. Dos Santos E.J.; De Oliveira, E. Determination of mineral nutrients and toxic elements in Brazilian soluble coffee by ICP-AES. J. Food Compos. Anal. 2001, 14, 523-531.

11. Gutu, S.Z. Policy Options for Ethiopia's Coffee Exports, Montclair State University, New Jersey, USA; 1998.

12. ICS Research, Chemical Composition of Coffee, Institute for Coffee Studies, Vanderbilt University Medical Center, Nashville Tennessee, USA; 2001.

13. Illy, E. The complexity of coffee. Sci. Am. 2002, 286, 86-91. 
Assessment of metals in roasted indigenous coffee varieties of Ethiopia

14. Tagliaferro, F.S.; De Nadai Fernandes, E.A.; Bode, P.; Bacchi, M.A.; De França, E.J. Candidate Coffee Reference Material for Element Content: Production and Certification Scheme Adopted at Cena/USP, Metrologia, Brazil; 2003.

15. Cuong, T.V.; Ling, L.H.; Quan, G.K.; Jin, S.; Jie, S.S.; Linh, T.L.; Tiep, T.D. Effect of roasting conditions on concentration in elements of Vietnam robusta coffee. Acta Universitatis Cibiniensis Series E: Food Technology 2014, 18, 19-34.

16. Gebretsadik, A.T.; Berhanu, T.; Kefarge, B. Levels of selected essential and nonessential metals in roasted coffee beans of Yirgacheffe and Sidama, Ethiopia. Am. J. Environ. Protect. 2015, 4, 188-192.

17. Martin, M.J.; Pablos, F.; Gonzalez, A.G. Characterization of green coffee varieties according to their metal content. Anal. Chim. Acta 1998, 358, 177-183,

18. Martin, M.J.; Pablos, F.; Gonzalez, A.G. Characterization of arabica and robusta roasted coffee varieties and mixture resolution according to their metal content. Food Chem. 1999, $66,365-370$.

19. Anderson, K.A.; Smith, B.W. Chemical profiling to differentiate geographic growing origins of coffee. J. Agric. Food Chem. 2002, 50, 2068-2075.

20. Nabrzyski, M. Mineral Components in Foods in Chemical and Functional Properties of Food Components Sereies, Szefer P.; Nriagu J.O. (Eds.), CRC Press: Boca Raton; 2006.

21. Banerji, S.K. Environmental Chemistry, 2nd ed., Prentice Hall of India: New Delhi; 2005.

22. Rajaganapathy, V.; Xavier, F.; Sreekumar, D.; Mandal, P.K. Heavy metal contamination in soil, water and fodder and their presence in livestock and products. J. Environ. Sci. Technol. 2011, 4, 234-249.

23. Debebe, A.; Chandravanshi, B.S.; Wondimu, T. Metallic nutrients in enset (Ensete ventricosum) corm cultivated in Wolliso and Wolkite Towns in Ethiopia. SINET: Ethiop. J. Sci. 2012, 35, 71-80.

24. Wagesho, Y.; Chandravanshi, B.S. Levels of essential and non-essential metals in ginger (Zingiber officinale) cultivated in Ethiopia. Springer Plus, 2015, 4, Article No. 127. DOI: 10.1186/s40064-015-0899-5.

25. Ayele, E.; Urga, K.; Chandravanshi, B.S. Effect of cooking temperature on mineral content and antinutritional factors of yam and taro grown in southern Ethiopia. Int. J. Food Eng. 2015, 11, 371-382.

26. Weldegebriel, Y.; Chandravanshi, B.S.; Wondimu, T. Concentration levels of metals in vegetables grown in soils irrigated with river water in Addis Ababa, Ethiopia. Ecotoxicol. Environ. Saf. 2012, 77, 57-63.

27. Dos Santos, J.S.; Dos Santos, M.L.P.; Conti, M.M.; Dos Santos, S.N.; De Oliveira, E. Evaluation of some metals in Brazilian coffees cultivated during the process of conversion from conventional to organic agriculture. Food Chem. 2009, 115, 1405-1410.

28. Pohl, P.; Stelmach, E.; Welna, M.; Szymczycha-Madeja, A. Determination of the elemental composition of coffee using instrumental methods. Food Anal. Methods 2013, 6, 598-613.

29. Nędzarek, A.; Tórz, A.; Karakiewicz, B.; Clark, J.S.; Laszczyńska, M.; Kaleta, A.; Adler, G. Concentrations of heavy metals (Mn, Co, Ni, Cr, Ag, Pb) in coffee. Acta Biochim. Polonica, 2013, 60, 623-627.

30. Ashu, R.; Chandravanshi, B.S. Concentration levels of metals in commercially available Ethiopian roasted coffee powders and their infusions. Bull. Chem. Soc. Ethiop. 2011, 25, $11-$ 24.

31. Mehari, B.; Redi-Abshiro, M.; Chandravanshi, B.S.; Combrinck, S.; McCrindle, R. Characterization of the cultivation region of Ethiopian coffee by elemental analysis. Anal. Lett. 2016, 49, 2474-2489.

32. Exporters - Coffee Cleaners and Graders, Coffee Specialties for Roasters from Ethiopia, MOPLACO Trading Co. Ltd. Ethiopia: Addis Ababa, Ethiopia; 1999. 
33. Suseela, B.; Bhalke, S.; Kumar, A.V.; Tripathi, R.M.; Sastry, V.N. Daily intake of trace metals through coffee consumption in India. Food Addit. Contam. 2001, 18, 115-120.

34. Miller, J.N.; Miller, J.C. Statistics and Chemometrics for Analytical Chemistry, 5th ed., Pearson Practice Hall: England; 2005.

35. Onianwa, P.C.; Adetola, I.G.; Iwegbue, C.M.A.; Ojo, M.F.; Tella, O.O. Trace heavy metal composition of some Nigerian beverages and food drinks. Food Chem. 1999, 66, 275-279.

36. Christian, G.D. Analytical Chemistry, 2nd ed., John Wiley and Sons: New York; 2004.

37. National Research Council Recommended Dietary Allowances, 10th edition. Food and Nutrition Board, National Academy Press: Washington, DC; 1989.

38. Food and Nutrition Board Recommended Daily Intake of Minerals, Institute of Medicine, National Academies: USA; 1997. 